\title{
高齢者日常利用施設に対する生 ACCESSIBILITY TO LOCAL FACILITIES 活利便性に関する研究 : 千葉県 OF ELDERLY PEOPLE : IN THE CASE 内市町村の場合 OF CHIBA PREFECTURE
}

$\begin{array}{ll}\text { 山岸輝樹—— } & * 1 \\ \text { 鈴木雅之—岩片優二 }-2\end{array}$

服部岑生 — * 5

キーワード :

高齢者, 生活利便性, 住環境評価, 地域施設, 移動距離

Keywords:

Elderly people, Accessibility, Residential evaluation, Regional facilities, Travel distance

\author{
Teruki YAMAGISHI \\ Masayuki SUZUKI \\ Mineki HATTORI
}

This study aims to understand accessibility of residential area to dailyuse local facility of elderly people, and clarifies the characteristics of municipality in Chiba prefecture.

We estimate the number of people who can access to the nearest facilities on foot. Then by applying these data to cluster analysis, we classify municipalities into 7 clusters in which to describe their characteristics.

If the population density decreases, accessibility of residential area to local facility becomes worse. Particularly, the characteristics of residential area relate to the proximity of clinic, community center or library.

\section{1.はじめに}

平成 24 年、我が国の 65 歳以上の人口は $24.1 \%$ に昇し、ます ます高齢化が進んでいる。誰もが自宅を中心に地域にある施設や サービスなどを組み合わせ、その人らしい多様で個性的な生活を 送っているが、歳を重移動能力が低下した高齢者は日常生活圏が 縮小し、満足な住生活が行えなくなることがある。日常的な徒歩圏 内の施設内容が生活の質に大きな影響を及ぼし、施設の有無が高齢 者の継続居住に対する重大な課題となる可能性がある。

なるべく長いあいだ在宅で生活できることは生活の質を維持する だけでなく介護の限界点を引き上げることにつながるため、地域、 住まいとともに、福祉、医療が連携し地域社会づくりを行なうこと が求められている。国による「歩いて暮らせる地域づくり」構想を はじめ、千葉県においても「高齢者保健福祉計画」1)や「地域福祉 支援計画」 ${ }^{2)}$ 、「住生活基本計画」 ${ }^{3)}$ などを通じて「高齢者が住み慣 れた地域で安心して生活できるような地域社会づくり」の取り組み が進められている。

高齢者が住みつづけることができる地域社会づくりを進めるため には、公共サービスを高齢化した地域社会に対応したものへと再編 をはかる必要がある。実際には施設配置や提供されるサービスに よって、居住地ごとに利便性に差（生活格差）が生じていることが 予想されるが、この実感的な生活格差を評価する情報が提供されて おらず、現状の生活を的確に把握し地域の改善に資する情報が十分 に整えられていないと言える。

自立した生活を送る高齢者の地域生活・地域施設利用に関寸る 研究として、高齢者の外出頻度と地域環境の質に関寸る研究 ${ }^{4)}$ や、
地域の物理的・社会的環境亡高齢者の日常的な関わりに関する研究 5)6) 、地域施設の利用構造に関寸る研究 ${ }^{7)}$ 、高齢者の外出・散歩行動 と屋外環境に関する研究 ${ }^{8)}$ 、住宅地の生活環境に対する利用者側の 利便性の研究 ${ }^{9110) 11)}$ などがある。筆者らは高齢者の生活利便性によ る住環境評価方法とその評価を見える化する方法の提案を行い、そ れらを用いた地域比較を行っている ${ }^{12)}$ 。

本研究は千葉県全域の居住地を対象とし、高齢者が日常利用する 地域施設に対する近接性からみた居住地の生活利便性の把握を行な い、市町村ごとの特性を明らかにすることを目的とする。そのうえ でまとめとして行政課題に対応する新しい行政データとしての有効 性の考察を行なう。

\section{2. 研究の方法}

千葉県内市町村の全居住地において、高齢者の日常生活で重要と 考えられる地域施設までの距離を計測し、徒歩で地域施設まで到達 可能な人口の推計を行ない、市町村ごとの利便性の把握を行なう。

高齢者の日常的な地域施設利用については、一般的な住生活にお ける施設利用に加え高齢者専用施設の利用があると想定し、既往文 献を参考に作成した表 1 の地域施設一覽注 1$)$ から高齢者が生命・健 康や社会生活の維持のため施設まで赴きサービスを受けるもので、 かつ頻度・重要度が高いと考えられる 6 種の施設を最低限必要な施 設として選択する注2) 注3)。

住宅地については、詳細かつ一定のまとまりをもった地域居住 データとしての情報が必要である。本研究では住宅地の基本単位と して生活実態に近い街区をその単位とし、実際には街区レベルに相

\footnotetext{
NPO 法人ちば地域再生リサーチ 研究員・博士（工学）

（干167-0034 東京都杉並区桃井 3-7-2-1401）

(林岡村製作所 修士 (工学)

千葉大学キャンパス整備企画室 助教・博士 (工学)

日本大学生産工学部 教授・博士 (工学)

千葉大学 名誉教授・工博
}

\footnotetext{
Researcher, Chiba Regional Revitalization Research, Dr. Eng.

Okamura Corporation, MA. Eng.

Assistant Prof., Campus Planning Office, Chiba Univ., Dr. Eng.

Prof., Dept. of Architectural Engineering, College of Industrial Technology, Nihon Univ., Dr. Eng.

Prof. Emeritus, Chiba Univ., Dr. Eng.
} 
当する国勢調查の「基本単位区」（平成 22 年）注 4 ）を利用する。居 住者は最も近い施設を利用寸るものとし、居住地から施設までの 距離は基本単位区重心から最も近い施設までの直線距離とする注5)。 基本単位区ごとの高齢者人口は公表されていないため、公表されて いる全年齢を含む人口を利用する。そのため本研究には高齢者の生 活実態を示すことができないという限界はあるが、高齢者にとって の居住地の利便性把握は可能であると判断した。

徒歩圈については既往文献を参考に一般市民の徒歩圈を $1 \mathrm{~km}$ 、身 体機能が衰えてた高齢者の徒歩圏を $500 \mathrm{~m}$ と設定し分析を行なう注6)。

千葉県内自治体を地域によって分類する方法は多数あるが、ここ では「住生活基本計画」のなかで示されている 11 ブロックによる 分類（図 1 ）を利用する。各自治体の特性は表 2 に示す。

表 1 地域施設

\begin{tabular}{|c|c|c|}
\hline 分類 & 地域施設 & \\
\hline 商業、業務 & 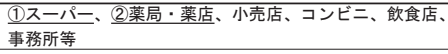 & \multirow{8}{*}{$\begin{array}{l}\text { 選択理由: } \\
\text { 1)食品購入 } \\
\text { (2)般薬購入 } \\
\text { (3)財産管理 } \\
\text { (4)生きがい } \\
\text { (5医療受診 } \\
\text { (6)謢サービース }\end{array}$} \\
\hline 金融、通信 & (3)銀行、郵便局、宅配ターミナル等 & \\
\hline $\begin{array}{l}\text { 教育、集会、 } \\
\text { スポーツ }\end{array}$ & 集会所、年図書館、公民館、運動広場、プール等 & \\
\hline $\begin{array}{l}\text { 生成、医療、 } \\
\text { 福祉 }\end{array}$ & $\begin{array}{l}\text { (5)病院・診療所、保健所、6 高齢者福祉施設、理美容院、 } \\
\text { クリーニンク等、 }\end{array}$ & \\
\hline 行政 & 市役所、出張所、警察署等 & \\
\hline 余暇、娛楽 & 公園、緑地、広場、映画館、興業施設等 & \\
\hline 交通·運輸 & 鉄道駅、バスターミナル、タクシー乗り場等 & \\
\hline 宗教・葬祭 & 神社、寺院、教会、葬祭場等 & \\
\hline
\end{tabular}

千葉県全体の結果概要を表 3 に示す。スーパー、薬局・薬店、銀 行・郵便局、高齢者福祉施設で平均距離 $500 \mathrm{~m} \sim 600 \mathrm{~m}$ 台である。こ れらの施設には県民の約 8 割が $1 \mathrm{~km}$ 未満の移動でアクセス寸ること が可能であり、さらに 5 〜 割が $500 \mathrm{~m}$ 未満の移動でアクセスが可 能である。図書館・公民館や内科・整形外科では平均距離がそれ ぞれ $879 \mathrm{~m} 、 1,014 \mathrm{~m}$ と $3 \sim 400 \mathrm{~m}$ 長く、さらに第 3 四分位も 1,458 $\mathrm{m} 、 1,771 \mathrm{~m}$ と平均との差も大きいなど前出 4 施設に比べ近接性が 低い。住宅からすべての施設が $1 \mathrm{~km}$ 未満の距離にある県民の割合は 約 $57.4 \% 、 500 \mathrm{~m}$ 未満の距離にある県民が $10.1 \%$ である。

\section{3. 徒歩圏に施設のある人口の割合}

\section{1.スーパー（図 2 )}

千葉・市原ブロック（以下 BL）、葛南 BL、東葛飾 BL にある人口 密度が 3,000 人 $/ \mathrm{km}^{2}$ 以上の人口密度が特に高い自治体では $1 \mathrm{~km}$ 未 満にスーパーのある人口は 9 割以上で、一般的な意味でほぼすべて の居住者の徒歩圏にスーパーがあると言える。高齢者の徒歩圏を想 定した $500 \mathrm{~m}$ 未満にスーパーのある人口も 6 〜 8 割と高い割合であ る。同じ BL 内の人口密度が 1,500 人 $/ \mathrm{km}^{2}$ 程度である若葉区や緑区、 野田市では $1 \mathrm{~km}$ 未満は約 8 割、 $500 \mathrm{~m}$ 未満は約 5 割である。人口密 度が若葉区などと同程度である印旛 BL・君津 BL の白井市、佐倉市、 木更津市などもほぼ同様である。八街市や印西市などでは $1 \mathrm{~km}$ 未満 にスーパーがある割合が 6 〜 割とさらに低い。スーパーが $500 \mathrm{~m}$ 未満にある割合も $3 \sim 4$ 割程度である。

その他の BL では銚子市、旭市、九十九里町、館山市など人口密 度が 500 人 $/ \mathrm{km}^{2}$ 程度の市町村で $1 \mathrm{~km}$ 未満が $7 \sim 8$ 割程度、 $500 \mathrm{~m}$ 未 満が 5 割程度の自治体があるものの、その他の自治体は $1 \mathrm{~km}$ 未満は 6 割程度であり、特に神崎町や芝山町、長柄町などで $1 \mathrm{~km}$ 未満の割 合が 4 割を下回る。これらの市町村では $500 \mathrm{~m}$ 未満にスーパーのあ

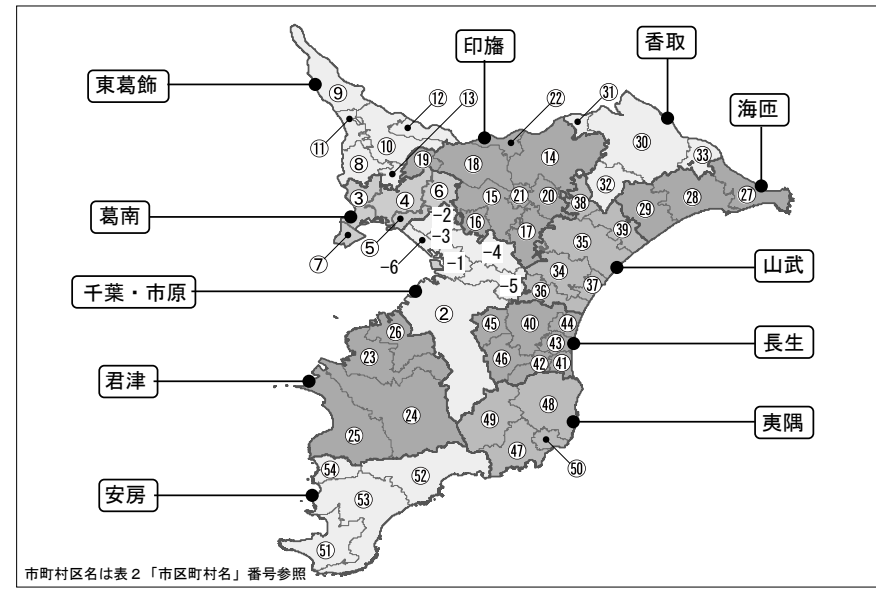

図 1 千葉県 11 ブロック

表 2 ブロック別の自治体特性

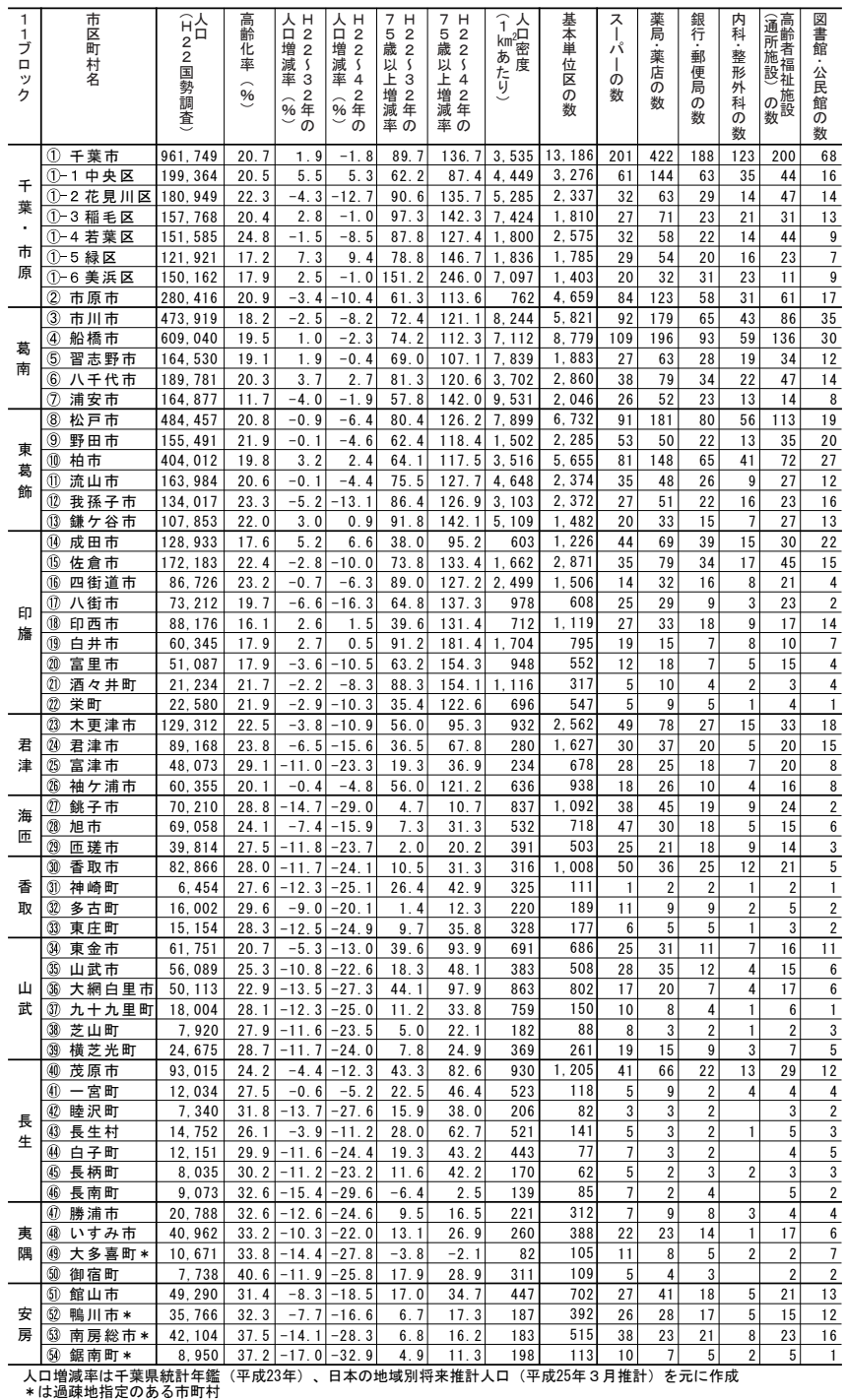

表 3 県全域結果概要

\begin{tabular}{|c|c|c|c|c|}
\hline & 平均距離 & 第 3 四分位距離 & $1 \mathrm{~km}$ 未満人口の割合 & 500m 未満人口の割合 \\
\hline スーパー & $541 \mathrm{~m}$ & $916 \mathrm{~m}$ & $88.6 \%$ & $60.8 \%$ \\
\hline 薬局‧薬店 & $554 \mathrm{~m}$ & $910 \mathrm{~m}$ & $88 / 0 \%$ & $67.2 \%$ \\
\hline 銀行·郵便局 & $638 \mathrm{~m}$ & $1,094 \mathrm{~m}$ & $84.2 \%$ & $51.1 \%$ \\
\hline 図書館·公民館 & $879 \mathrm{~m}$ & $1,458 \mathrm{~m}$ & $72.8 \%$ & $32.0 \%$ \\
\hline 内科·整形外科 & $1,014 \mathrm{~m}$ & $1,771 \mathrm{~m}$ & $72.8 \%$ & $38.4 \%$ \\
\hline 福祉施設（通所） & $630 \mathrm{~m}$ & $1,053 \mathrm{~m}$ & $85.3 \%$ & $54.9 \%$ \\
\hline
\end{tabular}




\section{る人口は 1 ～ 2 割程度である。}

\section{2. 薬局 ·薬店（図 3 )}

千葉・市原 BL、葛南 BL、東葛飾 BL の人口密度が 3,000 人 $/ \mathrm{km}^{2}$ 以上である市町村では $1 \mathrm{~km}$ 未満に薬局・薬店がある人口が 9 割を超 え、 $500 \mathrm{~m}$ 未満も 8 割を超える。印旛 BL、君津 BL の佐倉市や四街道 市、白井市など人口密度が 1,500 人 $/ \mathrm{km}^{2}$ 以上である市町村は $1 \mathrm{~km}$ 未満が 9 割、 $500 \mathrm{~m}$ 未満が 6 〜 割である。これらのブロックではスー パーよりも薬局・薬店の方が近接性が高い。

その他の BL では銚子市、茂原市で $1 \mathrm{~km}$ 未満に薬局・薬店のある 人口が 8 割程度、 $500 \mathrm{~m}$ 未満の人口が $5 \sim 6$ 割程度とスーパーとほ ぼ同程度の市町村もあるが、ほとんどの自治体ではスーパーよりも 近接性が低い傾向にある。特に芝山町、長柄町、長南町では $1 \mathrm{~km}$ 未 満に薬局・薬店のある人口の割合が 3 割以下である。 $500 \mathrm{~m}$ 未満に 薬局・薬店のある人口も 1 割に満たない。スーパーと比べると密住 地と疎住地の差が大きい。

\section{3. 銀行 · 郵便局（図 4)}

千葉市中央区や船橋市など人口密度が 3,000 人 $/ \mathrm{km}^{2}$ を超える千

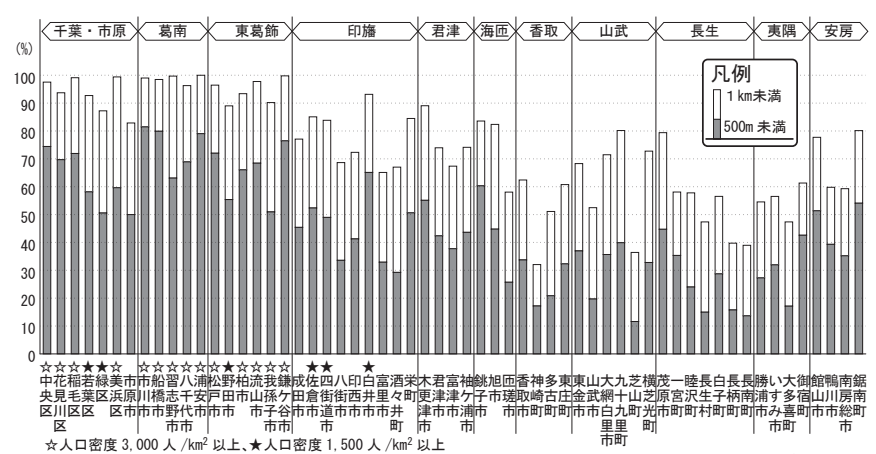

図 2 スーパー密
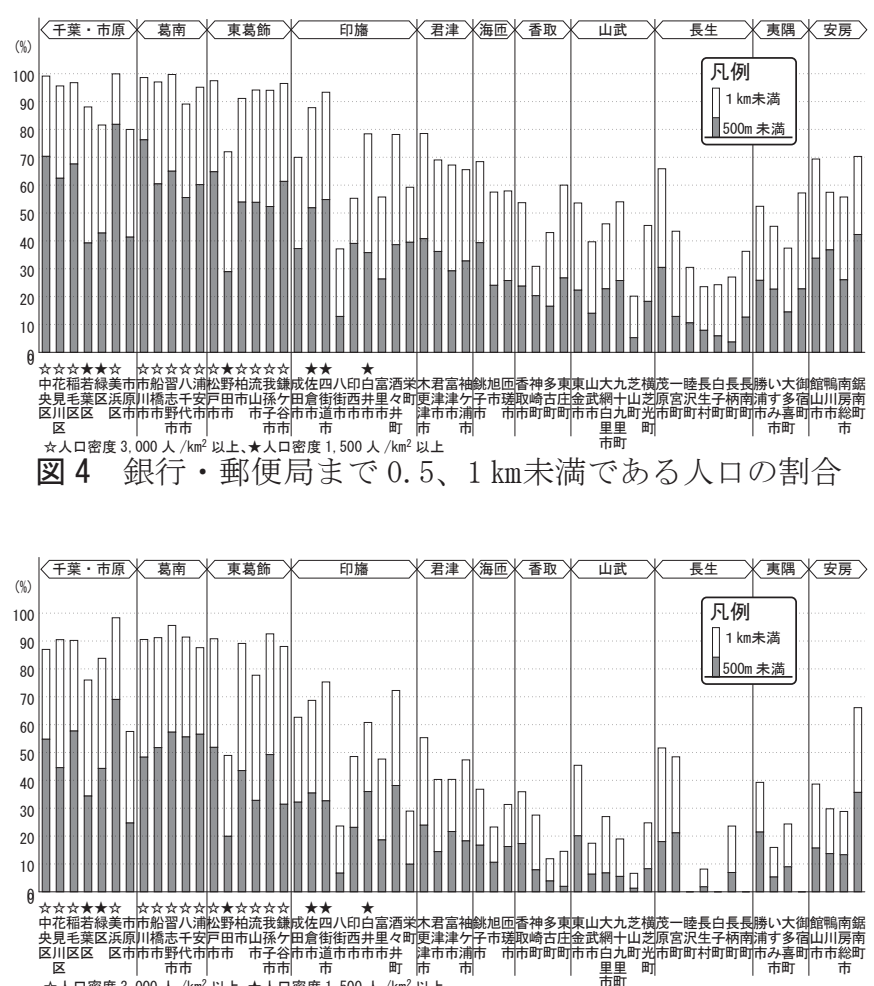

図6 内科・整形外科まで $0.5 、 1 \mathrm{~km}$ 未満である人口の割合
葉・市原 BL、葛南 BL、東葛飾 BL の市町村では $1 \mathrm{~km}$ 未満に銀行・郵 便局がある割合が 9 割を超え、 $500 \mathrm{~m}$ 未満に銀行・郵便局がある割 合も 5 〜 割である。人口密度が 1,500 人 $/ \mathrm{km}^{2}$ 程度である若葉区、 緑区では $1 \mathrm{~km}$ 未満に銀行・郵便局のある人口は約 8 割、 $500 \mathrm{~m}$ 未満 にある割合は約 4 割と若干低い。野田市のように $1 \mathrm{~km}$ 未満が約 7 割、 $500 \mathrm{~m}$ 未満が約 3 割と特に低い市町村もあるが、全般的にはスーパー と同程度である。

印旛BL、君津 BL では佐倉市や四街道市、白井市等の人口密度 1,500 人 $/ \mathrm{km}^{2}$ 程度の市町村で $1 \mathrm{~km}$ 未満が 9 割程度、 $500 \mathrm{~m}$ 未満が 5 割程度であり、その他の市町村では $1 \mathrm{~km}$ 未満が $6 \sim 7$ 割程度、 $500 \mathrm{~m}$ 未満が 2 ～割とスーパーより低い。八街市はさらに近接性が低く、 $1 \mathrm{~km}$ 未満の割合が 4 割弱、 $500 \mathrm{~m}$ 未満の割合が 1 割強とこのブロック では特に低い。

その他のブロックの中では海匝 BL や安房 BL に比較的近接性の高 い自治体が多く、 $1 \mathrm{~km}$ 未満に銀行・郵便局のある人口が $6 \sim 7$ 割、 $500 \mathrm{~m}$ 未満にある人口が $2 \sim 4$ 割である。一方長生 BL では $1 \mathrm{~km}$ 未満 が $2 \sim 3$ 割、 $500 \mathrm{~m}$ 未満が 1 割程度の市町村が多いなど、比較的近

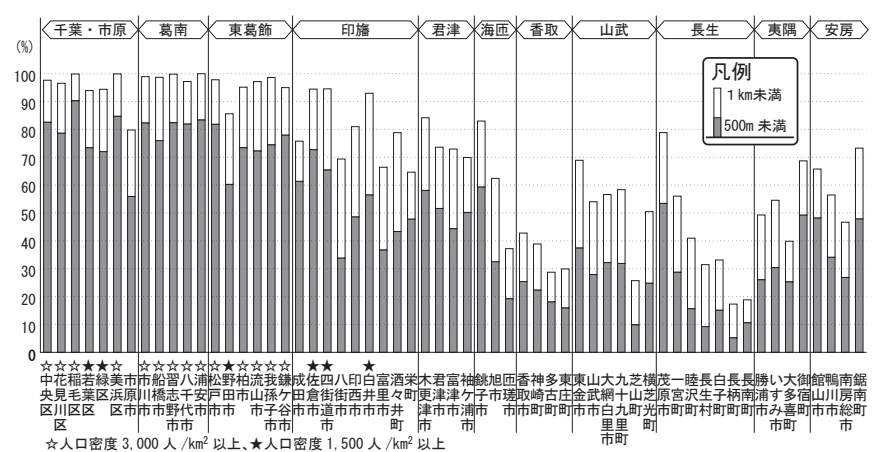

図3 薬局・薬店まで 0.5 、 $1 \mathrm{~km}$ 未満である人口の割合

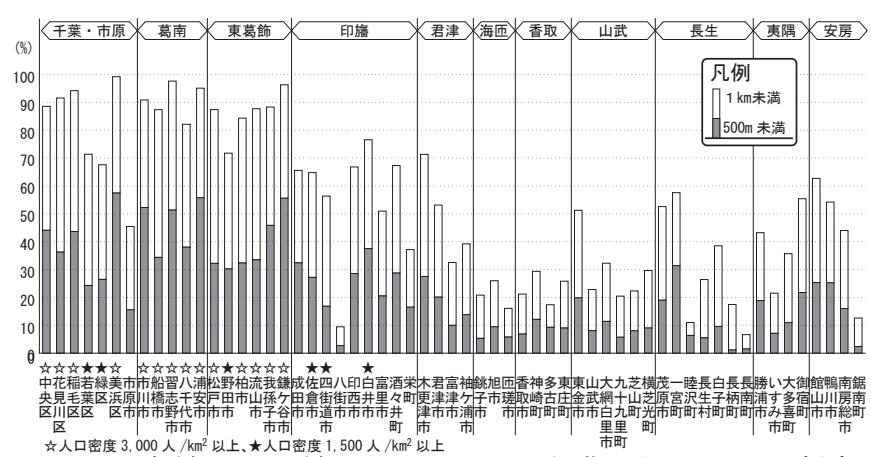

図 5 図書館・公民館まで $0.5 、 1 \mathrm{~km}$ 未満である人口の割合

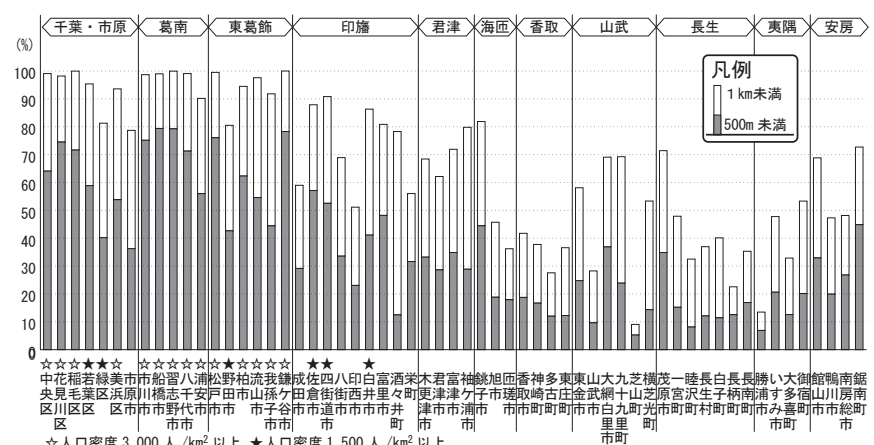

図7 福祉施設 (通所)まで $0.5 、 1 \mathrm{~km}$ 未満である人口の割合 
接性の低い市町村が多い。

\section{4. 図書館 · 公民館（図 5 )}

前出 3 施設同様、人口密度 3,000 人 $/ \mathrm{km}^{2}$ 以上の市町村では $1 \mathrm{~km}$ 未満に図書館・公民館のある人口が占める割合は $8 \sim 9$ 割と高いが、 $500 \mathrm{~m}$ 未満の人口は $3 \sim 6$ 割の市町村が多く、他の施設と比べると 割合が低い。千葉・市原 BL の中では市原市が $1 \mathrm{~km}$ 未満が 5 割弱で あるなど特に低い。印旛 BL、君津 BL では八街市の $1 \mathrm{~km}$ 未満が 1 割 に満たず特に低いが、ほかの市町村も $1 \mathrm{~km}$ 未満の人口が $4 \sim 7$ 割、 $500 \mathrm{~m}$ 未満の割合が 1 〜 割とばらつきがみられる。

その他の BL では $1 \mathrm{~km}$ 未満に図書館・公民館がある割合が 2 割弱 $\sim 4$ 割強の自治体が多い。茂原市や東金市、一宮市、御宿市で $1 \mathrm{~km}$ 未満の人口が 5 割程度の自治体がある一方、睦沢町、長南町では 1 $\mathrm{km}$ 未満が 1 割前後と差が見られる。安房 BL の館山市、鴨川市、南 房総市では $1 \mathrm{~km}$ 未満の割合が 4 〜 割と比較的割合が高い。

\section{5. 内科・整形外科（図 6)}

千葉・市原 BL、葛南 BL、東葛飾 BL の自治体では内科・整形外科 が $1 \mathrm{~km}$ 未満にある人口が $8 \sim 9$ 割、 $500 \mathrm{~m}$ 未満にある人口も 5 割前 後の市町村が多いが、市原市や野田市では $1 \mathrm{~km}$ 未満の人口が $5 \cdot 6$ 割、 $500 \mathrm{~m}$ 未満は 2 割程度とブロック内では比較的低い。印旛 BL では成 田市、佐倉市、白井市、四街道市、酒々井町で $1 \mathrm{~km}$ 未満の人口が 6 〜 割、 $500 \mathrm{~m}$ 未満が $3 \sim 4$ 割程度である一方、八街市や栄町では 1 $\mathrm{km}$ 未満が $2 \sim 3$ 割、 $500 \mathrm{~m}$ 未満が 1 割程度と近接性が低い。

その他の BL では君津 BL の木更津市や袖ケ浦市、山武 BL の東金 市や長生 BL の茂原市、一宮町で $1 \mathrm{~km}$ 未満が 5 割程度、 $500 \mathrm{~m}$ 未満が 2 割程度の市町村がみられる。一方内科・整形外科がその市町村に 無いため、0\%である自治体が長生 BL や夷隅BLにあり、特に低い 割合の自治体が複数ある。安房 BL の鋸南町は $1 \mathrm{~km}$ 未満が 7 割弱、 $500 \mathrm{~m}$ 未満が 3 割強と周辺自治体の中で特に高い割合を示している。

\section{6. 福祉施設（図 7 )}

千葉・市原 BL、葛南 BL、東葛 BL では人口密度が 1,500 人 $/ \mathrm{km}^{2}$ 程度の緑区や野田市などでも $1 \mathrm{~km}$ 未満が 8 割あり、その他のさらに 人口密度の高い市町村では $100 \%$ 似近い。500m の人口も6〜8 割あ り、スーパーの傾向に近い。

印旛 BL、君津 BL では佐倉市や四街道市、白井市、富里市で $1 \mathrm{~km}$ 未満が $8 \sim 9$ 割、 $500 \mathrm{~m}$ 未満が 4 〜 割であるのに対して、印西市 では $1 \mathrm{~km}$ 未満が 5 割、 $500 \mathrm{~m}$ 未満が 2 割と比較的低い、また酒々井 町は $1 \mathrm{~km}$ 未満が 8 割弱あるが、 $500 \mathrm{~m}$ 未満が 1 割強と少ない。

その他のブロックでは銚子市、大網白里市や茂原市、館山市など は $1 \mathrm{~km}$ 未満が 7 割を超える自治体がみられるが、 $1 \mathrm{~km}$ 未満の人口が 3 割程度の自治体が多く、特に芝山町や勝浦市で $1 \mathrm{~km}$ 未満が 1 割前 後と近接性が低い。

\section{4. 施設近接性の類型化}

各市町村における 6 種類の施設に対する近接性を総合的にとらえ るため、クラスター分析による類型化をおこない、類型ごとの特徴 を明らかにする。分析は各施設までの距離が $500 \mathrm{~m}$ 未満の人口の割 合と $1 \mathrm{~km}$ 未満の人口の割合を用いる。分析の結果得られたデンドロ グラム（図 8）をもとに、全体的な人口密度・施設密度だけでない

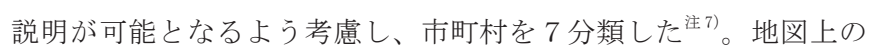
位置関係をみると東京都に近く、人口密度の高い市町村の類型 1 か

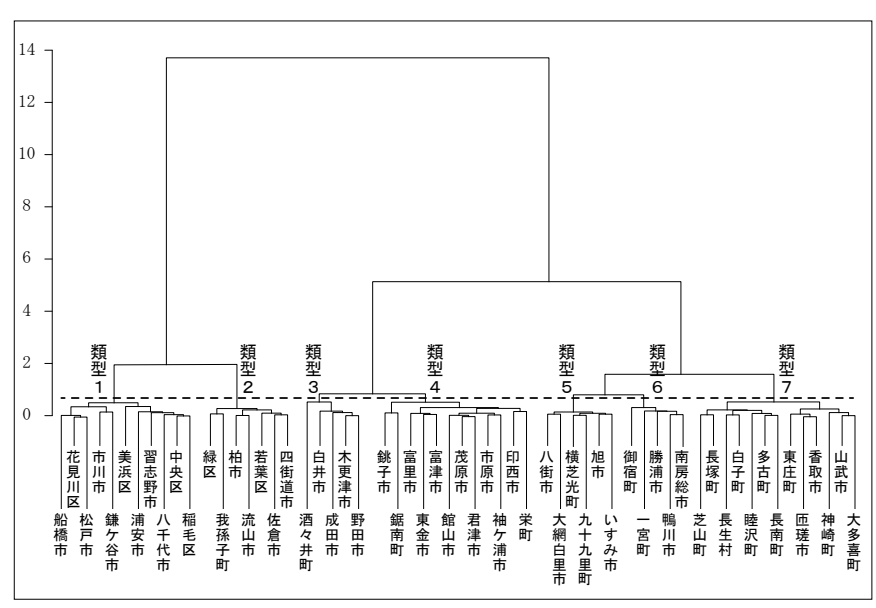

図 8 デンドログラム

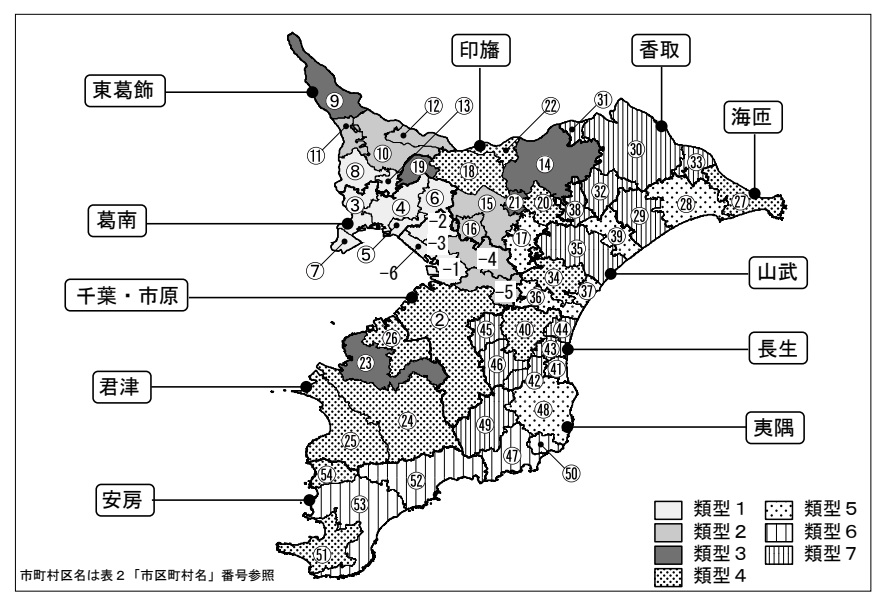

図 9 類型別市町村

ら同心円状に類型 2 、類型 3 と 4 、太平洋岸に類型 5 と 7 、半島の 先端に類型 6 の市町村がある（図 9)。

各類型の徒歩圈人口の割合の平均をレーダーチャートとして図 10 に示す。類型番号が大きいほど利便性が低い傾向がある。

類型 1 は人口密度が 4,000 人 $/ \mathrm{km}^{2}$ 以上の市町村で、葛南 BL の市 町村と松戸市、鎌ケ谷市、千葉市中央区、稲毛区、花見川区、美浜 区が含まれ、利便性が最も高い。これらの市町村では各施設とも人 口の 9 割以上が $1 \mathrm{~km}$ 未満で各施設に行くことができ、6 種施設のす べてが $500 \mathrm{~m} 、 1 \mathrm{~km}$ 未満にある人口の割合は平均でそれぞれ $16.8 \%$ 、 82. $3 \%$ である。

類型 2 は人口密度 1,600 人 $/ \mathrm{km}^{2}$ 以上の千葉・市原 $\mathrm{BL}$ 、東葛飾 BL, 印旛BL の市町村で千葉市若葉区、緑区、流山市、柏市、我孫子市、 佐倉市、四街道市が含まれる。各施設への近接性は $1 \mathrm{~km}$ 未満の割合 が平均 7 割を超え高いものの、類型 1 と比べ公民館・図書館、内科・ 整形外科に対する近接性が劣っている。6 施設すべてが $500 \mathrm{~m} 、 1 \mathrm{~km}$ 未満にある人口の割合はそれぞれ $5.6 \% 、 49.5 \%$ ある。

類型 3 は人口密度 $600 \sim 1,700$ 人 $/ \mathrm{km}^{2}$ で東葛飾 BL, 印旛 BL、君 津 BL の市町村である野田市、成田市、白井市、酒々井町、木更津 市である。類型 2 と比べ $500 \mathrm{~m}$ 未満の人口の割合が内科・整形外科 や高齢者施設をはじめ全体的に $1 \sim 2$ 割程度近接性が低い傾向があ る。6 施設すべてが $500 \mathrm{~m} 、 1 \mathrm{~km}$ 未満にある人口の割合の平均はそれ ぞれ $4.0 \% 、 37.5 \%$ である。 


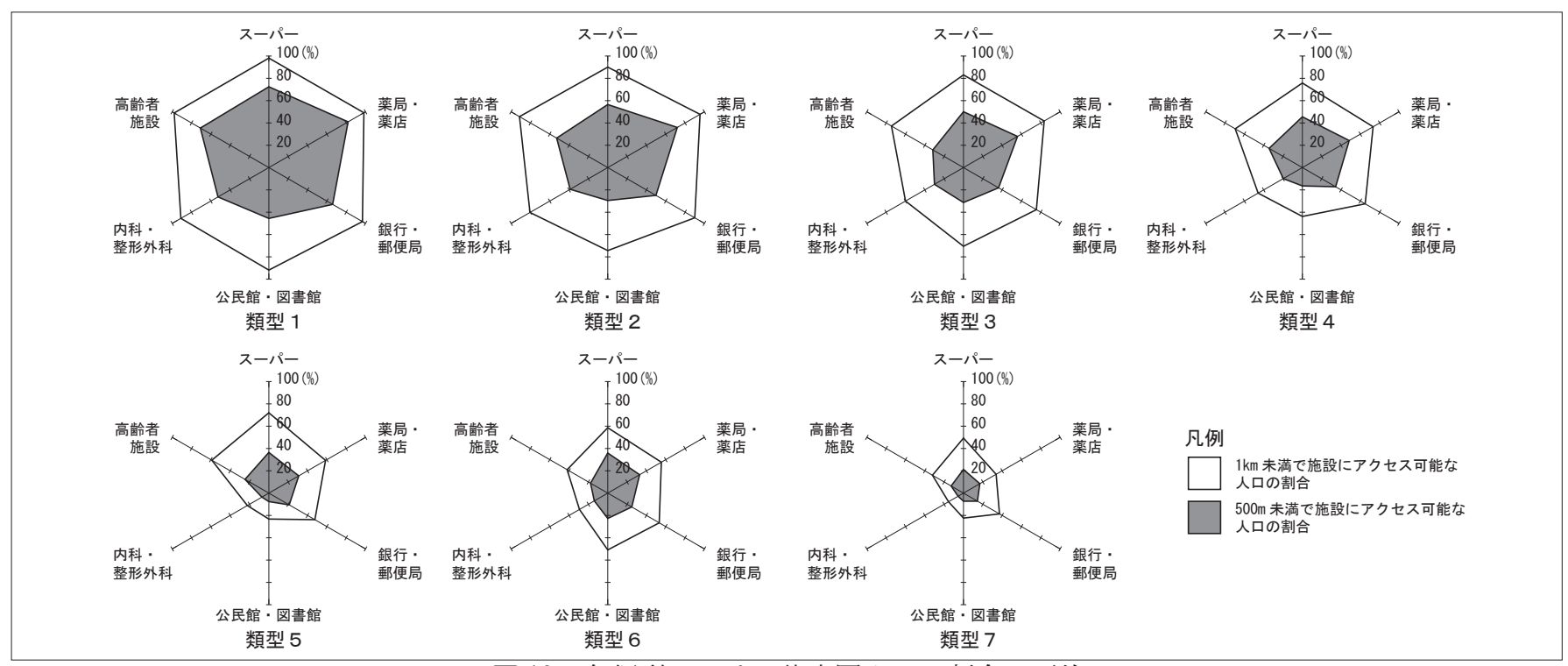

図 10 各類型における徒歩圈人口の割合の平均

類型 4 は人口密度は 200 人〜 $900 / \mathrm{km}^{2}$ で、千葉・市原 BL の市原 市、印旛BL の印西市、富里町、栄町、君津 BL の君津市、富津市、 袖ケ浦市、海匝BL の銚子市、山武 BL の東金市、長生 BL の茂原市、 安房 BL の館山市、鋸南町と県域に広くある類型である。類型 3 と 比べると $500 \mathrm{~m}$ 未満でアクセス可能な人口の割合が内科・整形外科、 図書館・公民館で 1 割程度低いがそれ以外は同程度である。一方で $1 \mathrm{~km}$ 未満でアクセス可能な人口の割合は各施設とも 1 割程度低い。 6 施設すべてが $500 \mathrm{~m}$ 未満にある人口の割合の平均は $1.8 \%$ と少ない。 $1 \mathrm{~km}$ 未満にすべての施設がある人口の割合の平均は $21.4 \%$ である。

類型 5 は人口密度が 260 人〜 960 人 $/ \mathrm{km}^{2}$ の市町村で、印旛 BL の 八街市、海匝BL の旭市、山武 BL の大網白里市、九十九里町、横芝 光町、夷隅 BL のい寸み市である。類型 4 と比べるとスーパーや高 齢者施設に対する平均的な近接性はほとんど変わらないものの、そ の他の施設に対して $500 \mathrm{~m}$ 未満の人口の割合が平均で 1 割程度低い。 $1 \mathrm{~km}$ 未満にすべての施設がある人口の割合の平均は $9.8 \%$ である。

類型 6 は人口密度が 180 人〜 500 人 $/ \mathrm{km}^{2}$ で、長生 BL の一の宮町、 夷隅 BL の勝浦市、御宿町、安房 BL の鴨川市、南房総市が含まれる。 類型 5 と比較するとスーパーや高齢者施設が $1 \mathrm{~km}$ 以内にある人口の 割合の平均は類型 5 よりも低いものの薬局・薬店や銀行・郵便局に 対する割合はほぼ同程度であり、公民館・図書館に対する近接性は 類型 5 よりも高い。勝浦市や御宿町では $1 \mathrm{~km}$ 以内にすべての施設が ある居住地はない。その他の一宮市や鴨川市、南房総市では $1 \mathrm{~km}$ 未 満にすべての施設がある人口の割合は 2 割前後である。

類型 7 はその他の香取 BL，海匝 BL，山武 BL、長生 BL、夷隅 BL の 市町村で人口密度が 80 人〜 520 人 $/ \mathrm{km}^{2}$ の市町村である。 $1 \mathrm{~km}$ 以内 に施設のある人口の割合はそれぞれの施設で $1 \sim 5$ 割程度であり、 $500 \mathrm{~m}$ 未満にある人口の割合は平均 2 割を下回る。この類型でも $1 \mathrm{~km}$ 未満で 6 施設がす心゙てそろう居住地がない市町村が複数みられる。

以上で得られた知見をとりまとめ、各類型の特徵を市町村の位置 関係や人口密度も踏まえモデル化したものが図 12 である。人口密 度の高い類型 1 から番号が大きくなるにつれ、施設に対する近接性 が下がっていくが、特に公民館・図書館と内科・整形外科に対する 近接性に差が大きい。類型 3 と類型 4 ではスーパーや薬局・薬店な

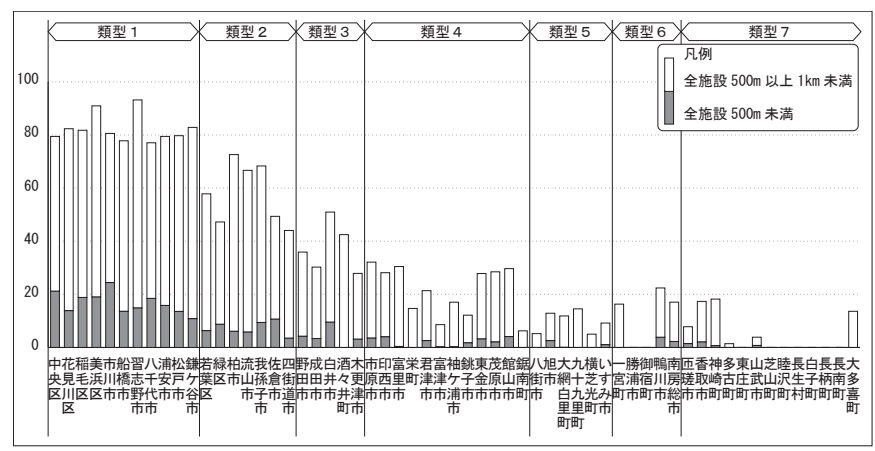

図 116 種施設すべてが $500 \mathrm{~m} 、 1 \mathrm{~km}$ 未満である割合

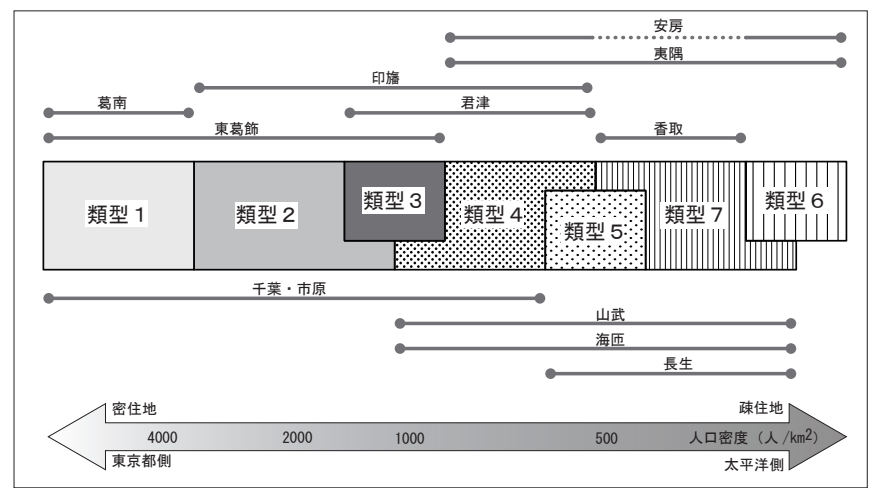

図 12 市町村類型の関係モデル

どに対する近接性はほぼ同程度であるが、公民館・図書館に対する 割合が類型 3 では類型 2 とほぼ変わらないくらい高いのが特徴で、 類型 4 は類型 3 と比べ内科・整形外科とともに近接性が低いのが特 徵である。類型 $5 \cdot 6$ を最も近接性の低い類型 7 と比べると、類型 5 ではスーパー、薬局・薬店、高齢者施設といった民間施設系の利 便性が高く、類型 6 では銀行・郵便局や公民館・図書館といった公 共施設系の利便性が高い。

\section{5. まとめ}

千葉県内市町村を対象に、高齢者の日常生活に重要な 6 種類の地 
域施設まで徒歩で到達可能な人口の推計を行い、さらにそれを元に 近接性を総合的にとらえるため類型化を行ない、類型ごとの特徴を 示した。

類型 1 や 2 では施設までの距離が $1 \mathrm{~km}$ 未満の割合がそれぞれ 9 割 以上で、健常時には徒歩での地域生活が広く行なわれていると考え られる。一方、類型 4 では 6 種施設がすべてが $1 \mathrm{~km}$ 未満にあるのは 人口の $2 \sim 3$ 割程度であり、日常的に徒歩圏だけでなくより広域で の生活が行なわれていることが多いと予想される。

一方で $500 \mathrm{~m}$ 未満にすべての施設がある人口は全県民の約 1 割、 人口密度が最も高い類型 1 の市町村においても 2 割前後であり、 $500 \mathrm{~m}$ 徒歩圈だけで生活を成立できる範囲が極めて小さい事を示し ている。

表 2 に 75 歳以上人口の 10 年後、20 年後における増加率を示し ている。類型 $1 \sim 3$ に属寸る、千葉・市原 B L 、葛南 B L、東葛飾 B L の市町村は今後 20 年の間に 75 歳以上が現在の 2 倍以上に増加 すると推定されている。類型 2 の市町村は施設まで $500 \mathrm{~m}$ 以上 $1 \mathrm{~km}$ 未満に居住する人口が全体の $3 \sim 4$ 割もあり、将来外出行動に問題 を抱える高齢者の数が急増する可能性があると言える。

以上から本研究で行なった利便性評価を指標とすることで、市町 村の居住性能を把握することが可能となり、また地域の課題把握の 助けになることから、行政データとして有効性があると考える。

注

注 1）参考文献 14）に谷口汎邦による都市的施設の 12 系統の施設分類, 参考 文献 15）には浦良一らの10 系統の分類、日本建築学会関東支部の研究 報告による 11 分類が示されおり、これらを参考に高齢者の日常生活と 関連すると考えられる 8 系統の地域施設一覧表を作成している。

注 2）理美容や市役所・出張所などは重要度が高いと考えられるが、日常的 な利用頻度が低いと考え対象施設から外している。またコンビニエン スストアは身近な施設として高齢者を含む住民に日常的に利用されて いるが、現時点においては高齢者にとって生命・健康・社会生活の維 持のための最低限必要な施設というほどの重要性はないものと考え、 今回は対象から外した。しかしコンビニはATM や行政空口の機能など も有するなど多機能化しており、地域のサービス拠点化が進んでいる。 高齢者の地域生活の中で、コンビニがどのような意味を持つのかを含 め、その扱いについては今後の課題としたい。

注 3）施設の住所情報の収集はそれぞれ以下の情報源を利用する。

\begin{tabular}{|c|c|}
\hline 施設種類 & 住所情報の収集方法（調查期間：平成 23 年 6 月～ 12 月） \\
\hline スーパー・銀行 & NTT 番号情報（株）「i タウンページ」（http://itp. ne. jp） \\
\hline $\begin{array}{c}\text { 内科・整形外科 } \\
\text { 薬局・薬店 }\end{array}$ & $\begin{array}{l}\text { 千葉県医療施設情報提供サービス「ちば医療ナビ」 } \\
\text { (http://www. iryo. pref. chiba. lg. jp) }\end{array}$ \\
\hline 郵便局 & 郵便局（株）（http：//www. jp-network. japanpost. jp） \\
\hline 公民館・図書館 & $\begin{array}{l}\text { 対象住宅地のある自治体（柏市、我孫子市、松戸市、船橋市、 } \\
\text { 習志野市）のホームヘヘージより集会施設および図書館を収集 }\end{array}$ \\
\hline $\begin{array}{l}\begin{array}{l}\text { 福祉施設 } \\
\text { (通所介護) }\end{array}\end{array}$ & $\begin{array}{l}\text { 千葉県介護サービス情報公表センター } \\
\text { (htp://www. kaigo. pref. chiba-la. jp) }\end{array}$ \\
\hline
\end{tabular}

薬局と薬店は処方せんに基づく医療医薬品を扱えるか否かの違いがあ るが、一般薬購入の重要性が高いと考え両方を対象とする。病院・診 療所は厚生労働省による平成 20 年 10 月患者調査にある 65 歳以上の疾 病分類別にみた推計患者数の構成割合によると、外来受診が多いのは 「筋骨格系及び結合組織の疾患」「循環器系の疾患」「消化器系の疾患」「内 分泌、栄養および代謝疾患」で合わせて 6 割を占める。病院・診療所 はこれらの疾病の診療科である内科・整形外科を対象とする。高齢者 福祉施設は自立生活が可能な高齡者の生活を想定しているため、在宅 介護事業所等は対象とせず通所介護サービス事業所を対象とする。

注 4）基本単位区は国勢調査に用いられる地域単位であり、住居表示を実施 している地域では原則として一つの街区となっている。

注 5）距離計測は歩行動線距離の計測が理想であるが技術的に難しく、また 直線距離の計測であっても比較検討する上では歩行動線距離と近似で きると考え、簡便な直線距離によって計測することとする。距離の算 出には街区及び地域施設の座標值データを用い、国内の近距離にのみ
適用可能な以下の近似式にを用いて計算を行った。2 点 $A 、 B$ の経度緯 度を $\left(\lambda_{\mathrm{A}} 、 \phi_{\mathrm{A}}\right)\left(\lambda_{\mathrm{B}} 、 \phi_{\mathrm{B}}\right)$ とした場合、

2 点間の距離 $\mathrm{D}(\mathrm{km})=\mathrm{R} \delta^{\circ} \pi / 180$

ただし $\mathrm{R}=6,370 \mathrm{~km}$ (日本付近での地球の曲率半径)

$\delta=\cos ^{-1}\left\{\sin \phi_{\mathrm{A}} \times \sin \phi_{\mathrm{B}}+\cos \phi_{\mathrm{A}} \times \cos \phi_{\mathrm{B}} \times \cos \left(\lambda_{\mathrm{A}}-\lambda_{\mathrm{B}}\right)\right\}$ （地球の中心よりみた 2 点間の角）

街区の位置情報は「基本単位区図形中心点座標データ」を用いる。施 設の位置情報は、東京大学空間情報科学研究センター「CSVアドレス マッチングサービス」(http://http://newspat. csis.u-tokyo. ac.jp/ geocode/) およびGoogle Map (http://maps. google. co.jp/) を利用し、 住所から緯度経度座標へ変換を行う。

注 6）参考文献 9）では徒歩による施設の利用想定地域を、施設を中心として $800 \mathrm{~m}$ 圈内、また参考文献 13）では利用圈を $500 \mathrm{~m}$ としているが、近接 性を評価することを考慮し $1,000 \mathrm{~m}$ まで距離を算出している。参考文献 10）では徒歩圈を一般的な状況下において徒歩で到達可能な範囲の最 大值としての意味合いを込めて $1,000 \mathrm{~m}$ としてい。参考文献 16) では 高齢者を含めて無理なく連続して歩ける距離を $300 ＼mathrm{~ 500 m ~ と し て い る 。 ~}$ 本研究では参考文献 9）13）16）にならい、一般的な意味での徒歩圈を $1,000 \mathrm{~m}$ 、高齢者の徒歩圈を $500 \mathrm{~m}$ として設定する。

注 7）クラスター分析はウォード法を用いた。

\section{参考文献}

1）千葉県: 千葉県高齢者保健福祉計画 平成 24 年度 平成 26 年度, 2012.3

2）千葉県：第二次千葉県地域福祉支援計画, 2010.3

3) 千葉県: 第 2 次千葉県住生活基本計画 平成 23 年度 平成 32 年 度, 2012.2

4）室永芳久, 両角光男 : 熊本市における高齢者の外出行動に関する研究 -1984 年 PT 調査源データを用いた分析, 日本建築学会計画系論文集 547, pp. 163-168, 2001.9

5）橘弘志, 高橋鷹志 : 地域に展開される高齢者の行動環境に関する研究 大規模団地と既成市街地におけるケーススタディ, 日本建築学会計画 系論文集 496, pp. 89-95, 1997.6

6）登張絵夢, 竹宮健司, 上野淳：農山村地域にみる高齢者の生活と地域 との関係に関する事例的研究-高齢者の生活における「地縁」に関す る研究, 日本建築学会計画系論文集 540, pp. 125-132, 2001.2

7) 浅沼由紀, 谷口汎邦, 天野克也：都市居住高齢者のかかりつけ医療 施設の利用特性について, 日本建築学会計画系論文集 488, pp. 121130, 1996. 10

8）大島秀明, 天野克也, 浅沼由紀, 谷口汎邦: 高齢者の外出行動と座り スペース利用に関する研究-品川区の場合, 日本建築学会計画系論文 集 563, pp. 171-177, 2003.1

9）森永武男, 有馬隆文, 萩島 哲, 坂井猛: 生活利便施設の分布から見 た生活環境に関する研究, 都市計画. 別冊, 都市計画論文集 35, pp. 991-996, 2000. 10

10）原拓也, 石坂 公一, 大橋佳子：地方中核都市における高齢者の徒歩 アクセシビリティ特性からみた住宅地の評価, 日本建築学会計画系論 文集 635, pp. 129-135，2009.1

11）増山篤：商業・医療施設へのアクセシビリティと高齢者の居住パター ンの関係 - 千葉県浦安市を対象とした実証分析：日本都市計画学会都 市計画論文集 42-2, pp. 72-79, 2007. 10

12）山岸輝樹, 鈴木雅之, 広田直行, 服部岑生 : 住宅地の生活利便性の 評価による高齢者の暮らしの比較研究, 日本建築学会計画系論文集 686, pp. 801-806, 2013. 04

13）鈴木雅之, 服部岑生 : ライフエリアのミクロ実態に関する記述モデル の検討 : ライフエリア法を用いた建築的市街地整備手法の基礎的研究 (1), 日本建築学会計画系論文集 565 , pp. 129-134, 2003.03

14）日本建築学会編 : 地域施設の計画 -21 世紀に向けた生活環境の創造, 丸善, 1995.9

15）柳沢忠, 谷村秀彦, 佐藤圭二, 桜井康宏, 藤谷幸弘, 今井正次 : 新建 築学大系 21 地域施設計画, 彰国社, 1984.3

16）歩いて暮らせる街づくり研究会編 : 歩いて暮らせる街づくりテクニカ ルガイド，ぎょうせい, 2003.3

[2013 年 6 月 19 日原稿受理 2013 年 8 月 27 日採用決定］ 